\title{
SOCIAL MEDIA AND PUBLIC RELATIONS COUNSELLING OF HIGHER SCHOOL TOP MANAGEMENT IN NIGERIA
}

\author{
Harvey G. O. Igben, PhD \\ Department of Mass Communication \\ Delta State University, Abraka \\ harveygo.igben@aol.co.uk +2348037717371 \\ Enebeli Lucas Madubuchukwu \\ Department of Mass Communication \\ Delta State University, Abraka
}

\begin{abstract}
Social media have improved the operations of public relations. The ability of social media to elicit immediate feedback has made social media veritable tools in the hands of public relations practitioners in counselling school management on corporate policies. This study explores the pattern of social media usage by public relations practitioners. It shows the level of impact made with the use of social media in public relations practice in influencing management on corporate policies. The study was guided by diffusion of innovation theory and system theory. Diffusion of innovation theory offers a solid and replicable framework for the process of moving an innovation through a social system over time. System theory deals with the interactivity that exist in an organisation as a social system. Using the descriptive design, questionnaire was administered on 170 purposively selected public relations practitioners in some selected institutions of higher learning across the country but only 120 responded. Findings show that public relations practitioners use social media in influencing top school management on corporate policies. This is evident as all the respondents affirmed that they use social media such as WhatsApp, Facebook, Twitter, Youtube, Instagram, among others to inform and influence top school management on corporate policies. The study concludes that social media are potent tools in influencing school's policy formulation and implementation. The study recommends that institutions of higher learning should formulate and implement productive ICT policies and public relations practitioners should be trained regularly on the use of social media with a consequent expectation of migrating from the analogue to digital culture.
\end{abstract}

KEYWORDS: Social media, counselling, top management, public relations, web 2.0, digital age

\section{INTRODUCTION}

Social media are fast becoming the most reliable tools especially for disseminating information that involves public relations practice in counselling, formulation and implementation of organisational policies. Social media which started in 1999 with hr.com have grown to about 253 social media sites in the world, (Ufuophu-Biri 2013). Social media include Facebook, whatsapp, instagram, Youtube, MySpace, Flickr, Twitter, Badoo ,etc. Social media are veritable tools for getting information about current occurrences and opinion survey which is the hub of public relations operations. 
According to Babatunde, Innocent, Ibe, Comfort and Emmanuel (2013), a good number of people rely on social media to express themselves and also pass information on issues that affect a vast majority of the society. The emergence of new communication technologies has influenced the process of information acquisition and dissemination.

In a research conducted to examine the use of social media in public relations practice in the Kenyan Government, it was found that the introduction of the new media has transformed the manner in which public relations experts relay their information to the public and how they receive feedback from the public through the use of WhatsApp, facebook, twitter, blogs, among others ( Sakali, 2015). It is pertinent to note that public relations is a management function. Toth, Serini, Wright \& Emig as quoted by Neill and Lee (2016) posit that responsibilities typically associated with the public relations manager include counselling management, making communication policy decisions, evaluating programme results, and planning public relations programmes. The emergence of the digital age came the significant need for the use of social media in the public relations practice. This has offered the opportunity for constructing what influence social media would have for public relations counselling of top management on corporate policies in institution of higher learning in the country. This brings to the front burner the question of how public relations officers use social media support the process of offering corporate policy directed counselling to top management of higher educational institutions in Nigeria.

In the school system, there is high level of compliance to the social media by staff and students. Many of them depend on the social media for information on activities within and outside the school. They use social media to share their thought, make inquiries, and react to posts shared by other members and non-members of the school community. With their smart phones, tablets and laptops, they monitor events through social media. This development has placed a burden on the public relations practitioners in the management system. It is the burden of meeting the information needs of their internal and external publics and at the same time examines their opinion and relates same to management in form of counselling for policy formulation and implementation. This study, therefore examine the influence of the social media in counselling on corporate policy in institutions of higher learning in Nigeria.

Social media is changing the way information is gathered, processed, disseminated among public relations practitioners. The social media again is changing the management function of the public relations especially with regards to counselling top management and influencing corporate policy formulation and implementation. Dedekuma (2013) postulates that management needs information that will enable it exercise necessary control; for feedback in form of statistics, report and so on; for decision-making purpose relating to production and sales, target deviation from plans and possible changes and improvement. The crux of the matter is that it is not yet certain as to the extent to which the social media support public relations practice in counselling top management on corporate policy of the higher Institutions of learning in this country. This is the gap that this study is set out to address. 
To investigate the influence of the social media in public relations counselling on corporate policy in institutions of higher learning in Nigeria the study was structured to achieve the following objectives:

1. To determine if public relations practitioners in the higher institutions use social media in course of their their practices

2. To determine the preferred social media used by public relations practitioners to counsel top management on corporate policy

3. To ascertain the level of utilization of social media by Public Relations practitioners in counselling management on corporate policy.

4. To asses whether social media have enhanced the public relations objectives in terms of counselling management on corporate policy

5. To identify the challenges of social media use by Public Relations practitioners in counselling top management on corporate policy.

The foregoing objectives further thrust up some questions that would offer useful guide in interrogating for the right answer to the general question of how social media influence public relations counselling of top management of institutions of higher learning on corporate policy in Nigeria. These questions are as follow:

1. Do public relations practitioners in the higher institutions of learning use social media in their practices in Nigeria?

2. What are the preferred social media that PR practitioners use in counselling management of institutions of higher learning on corporate policies Nigeria?

3. What is the level of social media utilization in the PR practitioners counselling of management of higher educational institutions on corporate policies?

4. How has the use of social media enhanced the achievement of public relations practitioners in counselling management on corporate policies?

5. What challenges militate against social media use in counselling management on cooperate policies?

\section{LITERATURE REVIEW}

This section reviews the concept of social media, conceptualization of Public Relations Roles. Kietzmann, Hermkens and Mccarthy as quoted by Agha (2017) writes that social media involve the use of mobile and web-based technologies to design highly interactive platforms by which individuals and communities share, create, converse and adjust user-generated content (UGC). Users-generated content is enabled by web 2.0. Web 2.0 is a term encompassing a second generation 'of internet-based and interactive applications that are developed around usergenerated and user-adjusted content such as blogs, podcast wikipedia, facebook, myspace to mention but a few

Social media penetration worldwide is ever increasing. Hasan (2014.p668) posits that today, the term information technology has ballooned to encompass many aspects of computer and technology, and the term has become very recognizable. 
Onyechi and Obono (2015) view social media as a two-way method of communication that grants people access to interact with friends or engage in complex social, economic and political discourse. In writing about Social media as tools for public relations operations, Waddel (2010) postulates that social media help public relations executive build more relationships across a wider landscape and in a suitable fashion never before possible. Social media enable professionals to maintain ongoing, quality relationships with customers and partners. In the book, New media and Public Relations, Vincent Hazelton, Jill Harrison Rexrode and William Kennan (2008) further claim that public relations is undergoing a revolution. In the same line, Matins Sorrell (2008) put it this way: there is risk and opportunities inherent in the more complex uncontrolled communication environment of the social media. But public relations practitioners are used to working in an uncontrolled environment. It is its natural territory. The social media are transforming the operations of the public relations and re-conceptualize it in a new dimension.

Rex Harlow as cited by Nwanne (2015:25) sees public relations as a "distinctive management function, which helps establish and maintain mutual lines of communication, understanding, acceptance and cooperation between an organization and its publics, involving the management of problems or issues, helps management to keep inform on, and responsive to public opinion, defines and emphasizes the responsibility of management to keep abreast of, and serving as an early warning system to help anticipate trends and uses research and sound ethical communication technologies as its principal tools." From the forgoing, helping the management to keep informed on and responsive to public opinion defines the counselling role of the public relations practitioners to top management for effective and efficient corporate policy formulation and implementation. The application of the principle of public relations to meet the goal of an organization by counselling management for proactive policies is termed corporate public relations.

Public Relations involves the formation and implementation of an organizations' procedures and policy regarding communication with its publics (Hasan 2015, p.517). Similarly, Ajala(2013) says that public relations is the art and science of analysing trend, predicting their consequences, counselling organization's leadership and implementing planned programmes of action which will serve both an organization's and public interest. Whatever might be the task of public relations as stressed by different definitions, counselling remains indispensable in the management of the organization as the hub of the organizational or corporate policy lies on the impact of the counselling offered by the public relations experts who have direct contact with organizational publics. This put them in a better light to counsel the top management for effective and efficient policy formulation and implementation. Igben (1997. p38) put it this way "public relations professional counsels or advises his client or organisation on policies and actions that would result in understanding, acceptance and goodwill". Counselling in this discourse involves advising administrators on alternative options, recommending strategies, choices in the light of public responsibilities to enable management take appropriate policy decisions. It therefore means that public relations is an expression of the philosophy in policy decisions. Daramola (2003, p.6) posits that public relations is most effective if it is represented in the boardroom, at the highest management level. 


\section{Theoretical Framework}

The theories that provides the intellectual framework on the importance of this study as it relates to the influence of the social media in counselling on corporate policies in Nigeria, are diffusion of innovation theory and the system theory. According to Babatunde, Innocent, Ibe, Comfort, and Emmanuel (2013.p.30), diffusion of innovation theory offers a solid and replicable framework for the process of moving an innovation through a social system over time. The concept of diffusion was first studied by the French sociologist, Gabriel Tarde in the late $19^{\text {th }}$ century. The study of diffusion of innovations took off in the subfield of rural sociology in the Mid-western United States in the 1920s and 1930s. At that level, it was a distinct paradigm. The idea was developed into a theory by E.M. Rogers in 1962. It originated in communication to explain how, over time, an idea or product gains momentum and diffuses or spreads, through a specific population or social system. The import of this diffusion is that people as part of a social system, adapt to a new idea, behaviour or product (Ezekiel, Angela and Adecine 2017. p.109). Adoption in this discourse means that a person does something differently than what they had previously done. Agha (2017) explains that "diffusion of innovations states that innovation that is, an idea, new technology, diffuses or spreads through a society in a predictable pattern. A few people will adopt an innovation as soon as they hear it. Others will take longer to try something new and still others will take much longer". Bryant and Thompson as quoted by Agha (2017) put it thus "'when a new media technology or another innovation is adopted rapidly by a great number of people, it is said to explode in to being. This theory is relevant to the study because social media are new veritable tools that corporate public Relations practitioners use in carrying out their corporate duties.

As stated earlier, another theory that is relevant to this discourse is the System theory. Bertalanffy (1950) was the first to introduce System theory but Kataz and Khan (1966) later introduced it into the organisational setting . Ezekiel, et al (2017), argue that system theory is an approach to organizations which likens the enterprise to an organism with interdependent parts, each with its own specific function and interrelated responsibilities. According to Nwanne (2015), an open system in an organisation takes into account that organizations must interact with the world around them in order to be successful. System theory is useful in public relations because it gives us a way to think about relationships. It is pertinent to state that system theory helps organizations to structure the internal functions by specifying the employees jobs and functions of an organization in that it counsels' management on favourable corporate policies. The public relations practitioners are the go-between, which explain the organization to its publics and interpreting the publics to the organization. The above function meanly forms the corporate policies of an organization.

As Ezekiel, et al (2017) put it, the effect of the system theory in management is that writers, educators, consultants and other professionals help managers to look at organisations from a broader perspective. Public relations practitioners advise the primary decision makers of the organisation, about problems and opportunities in the environment and help the decision makers respond to the environmental changes. This is one of the bases of corporate policy. This theory is relevant to this study as it reflect the practitioners dependence on the social media to counsel top management on corporate policies. 


\section{METHODOLOGY}

The study employed the survey method. The rationale for adopting this method is that it is suitable for eliciting the response of the public relations practitioners on the influence of social media in counselling on corporate policies of higher institutions of learning in Nigeria. Wiminer and Dominick (2000) as quoted by Babatunde et al (2013) argue that it can be used to investigate problems in realistic settings, adding that the method is also more economical.

Questionnaire was designed which was used to elicit general information about the study questions and objectives from public relations practitioners in the selected higher institutions of learning in the country. The rationale for the use of questionnaire was based on the effectiveness of the instrument to obtain diverse and unbiased opinions from the sampled population. Statistical package for social science (SPSS) was used to prove the validity and reliability of the instrument. Public relations practitioners in the higher institutions of learning in the country constitute the population of the study. The institutions consist of federal and state universities, private universities, federal and state polytechnics, federal and state colleges of education, federal and state technical colleges and monotechnics in the thirty-six states of the federation.

Public Relations officers were purposively sampled from selected schools subject to a maximum of four staff from the public relations department of the target institutions of higher learning in Nigeria.Out of the one hundred and seventy (170) copies of the questionnaire sent out by email, one hundred and fifty (150) respondents responded representing eighty eight(88) percent.

The choice for using purposive sampling technique is justified by Gupta (2002.69) who observed that when only a small number of sampling unit are in the universe, simple random selection may miss the important elements, whereas, purposive selection would certainly include them in the sample. This is owing to the fact that public relations practice is relatively new and consequent upon that, there are few public relations practitioners in corporate organisations, especially in the institutions of higher learning in Nigeria. This gave the overall sample size of One hundred and fifty (150) respondents. Data gathered was analyzed using tables of frequency, simple percentage, bar and pie charts and histogram to show the distribution of results and understanding of analysis.

\section{DATA ANALYSIS}

Table 1: Public relations practitioners in the institutions of higher learning use social media in their practice

\begin{tabular}{|l|l|l|}
\hline Use of social media & Frequency & Percentage \\
\hline Yes & 150 & 100 \\
\hline No & 0 & 0 \\
\hline Total & 150 & 100 \\
\hline
\end{tabular}


All the respondents agreed that they use social media for their professional practices. This is in accordance with Biri (2013) that social media have become very important in both interpersonal and mass communication globally.

Table 2 : Social media preference of the public relations practitioners

\begin{tabular}{|l|c|l|l|}
\hline S/N & Preference & Frequency & Percentage \\
\hline 1 & Facebook & 40 & 26.7 \\
\hline 2 & WhatsApp & 50 & 33.3 \\
\hline 3 & Instagram & 10 & 6.7 \\
\hline 4 & Youtube & 20 & 13.3 \\
\hline 5 & Twitter & 30 & 20 \\
\hline 6 & Myspace & - & - \\
\hline 7 & Blogs & - & - \\
\hline 8 & Podcast & - & - \\
\hline 9 & Wikipedia & - & - \\
\hline & Total & 150 & 100 \\
\hline
\end{tabular}

The findings from the above table show that public relations practitioners have the following order of preference for the use of social media: WhatsApp (33.3\%); Facebook (26.7\%); Twitter (20.0\%); Youtube (13.3\%); and Instagram ( 6.7\%). The findings show that WhatsApp is the most preferred social media used by public relations practitioners in counselling management on corporate policies. This is because WhatsApp is most suitable for the internal publics of an organisation. Note that this study deals with the public relations practitioners' use of social media to influence top management in policy making and implementation in institutions of higher learning in Nigeria. The school administrators are part of the internal publics of an organisation.

Diagram 1: Pie chart representing the preferred social media used by public relations practitioners 
European Journal of Business and Innovation Research Vol.9, No.2, pp. 39-52, 2021

Print ISSN: 2053-4019(Print),

Online ISSN: 2053-4027(Online)

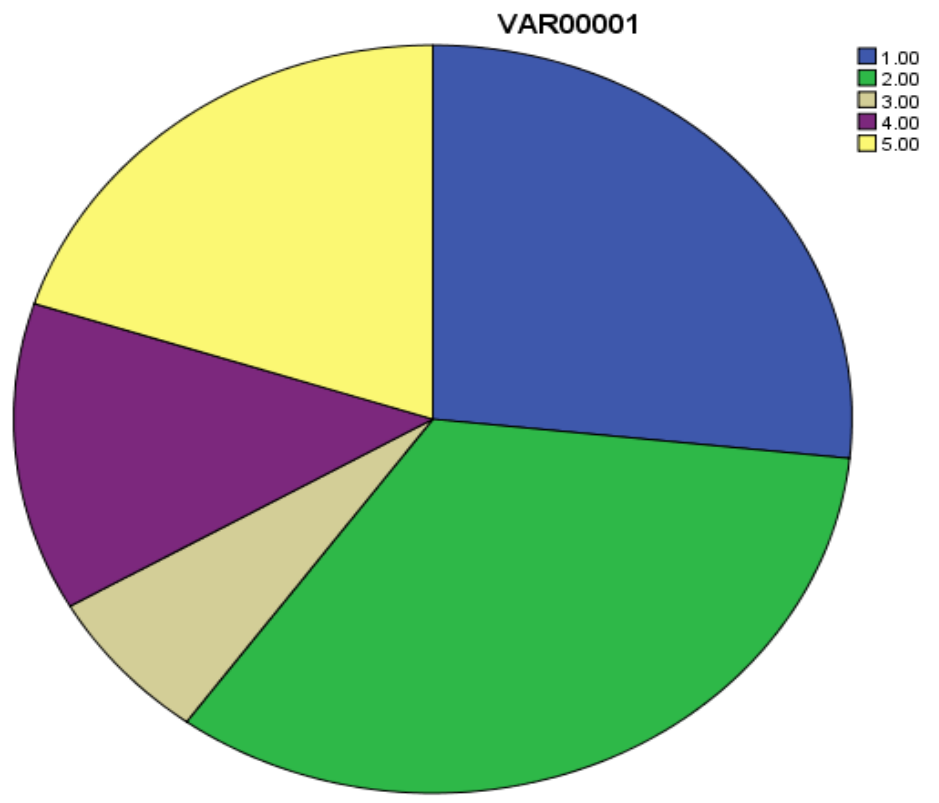

Key:

Facebook 1

WhatsApp 2

Instagram 3

Youtube 4

Twitter 5

Table 3: Level of social media utilization by public relations practitioners for counselling school management on corporate policies

\begin{tabular}{|l|l|l|l|}
\hline S/N & Level of usage & Frequency & Percentage \\
\hline 1 & Very high & 20 & 13.3 \\
\hline 2 & High & 60 & 40.0 \\
\hline 3 & Average & 40 & 26.7 \\
\hline 4 & Low & 20 & 13.3 \\
\hline 5 & Very low & 10 & 6.7 \\
\hline & Total & 150 & 100 \\
\hline
\end{tabular}

Table 3 above shows that $60(40.0 \%)$ of the respondents' usage of social media is high. Forty $(26.7 \%)$ of the respondents use social media on the average. Social media usage of $20(13.3 \%)$ is low, while $10(6.7 \%)$ claimed that their usage level is very low.

Diagram 2: Bar chart representing the level of social media utilization by public relations practitioners 


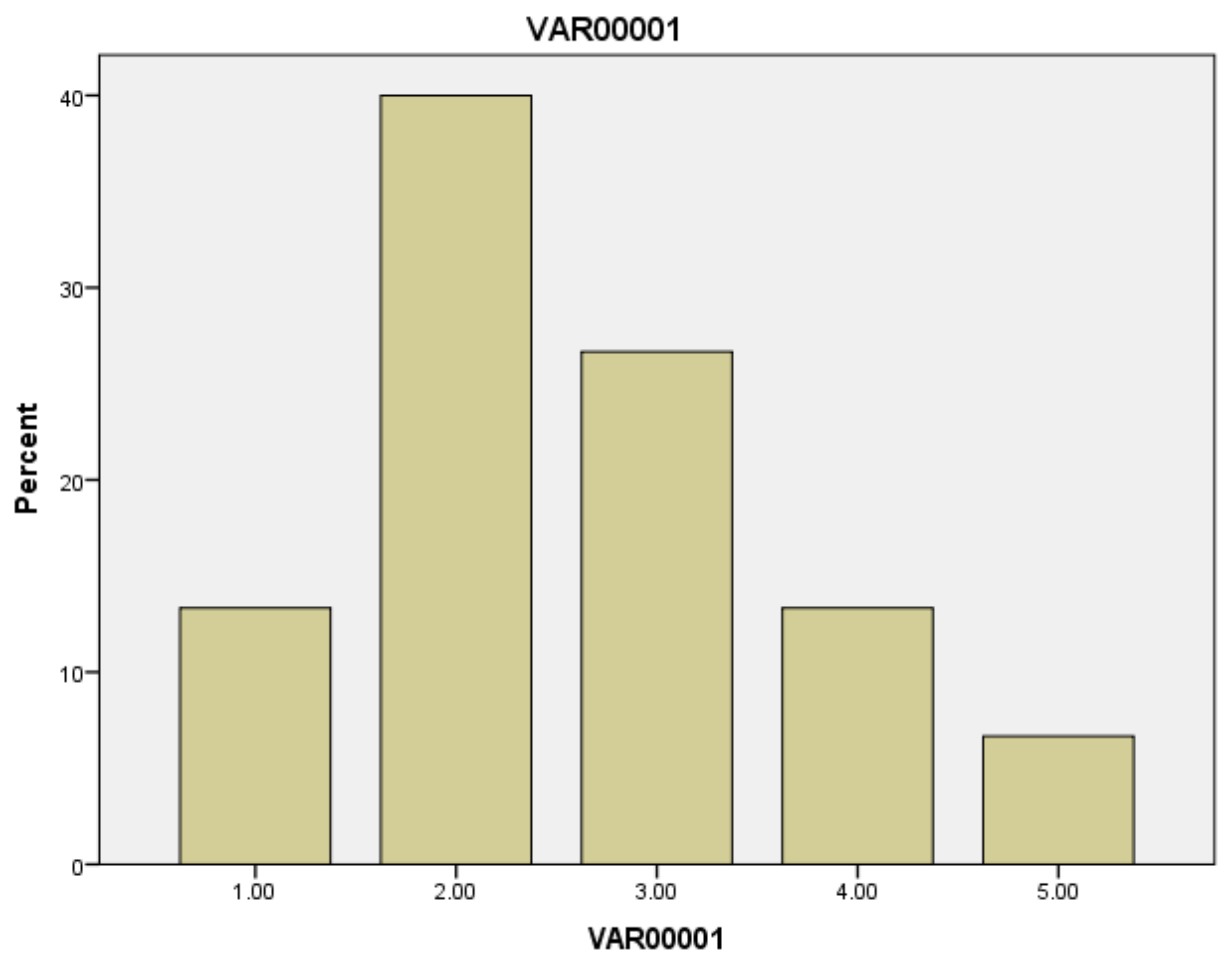

Table 4:Social media enhances the achievement of public relations practitioners' counselling of school management on corporate policies

\begin{tabular}{|l|l|l|l|}
\hline S/N & Enhancement & Frequency & Percentage \\
\hline 1 & Very high & 30 & 20 \\
\hline 2 & High & 50 & 33.3 \\
\hline 3 & Average & 40 & 26.7 \\
\hline 4 & Low & 20 & 13.3 \\
\hline 5 & Very low & 10 & 6.7 \\
\hline & Total & 150 & 100 \\
\hline
\end{tabular}

Table 4 above shows that $50(33.3 \%)$ of the respondents affirmed that social media enhancement of the achievement of counselling top school management on policy formulation and implementation is high. Forty $(26.7 \%)$ of the respondents claimed that social media enhancement of the achievement of counselling school management was on the average. Thirty (20.0\%) claimed that the enhancement is very high. Twenty $(13.3 \%)$ the the social media enhancement is low, while $10(6.7 \%)$ maintained that the enhancement very low in counselling school management on corporate policies.

Diagram 3: pie chart representing the level of enhancement made by the use of social media in counselling management on corporate policies 


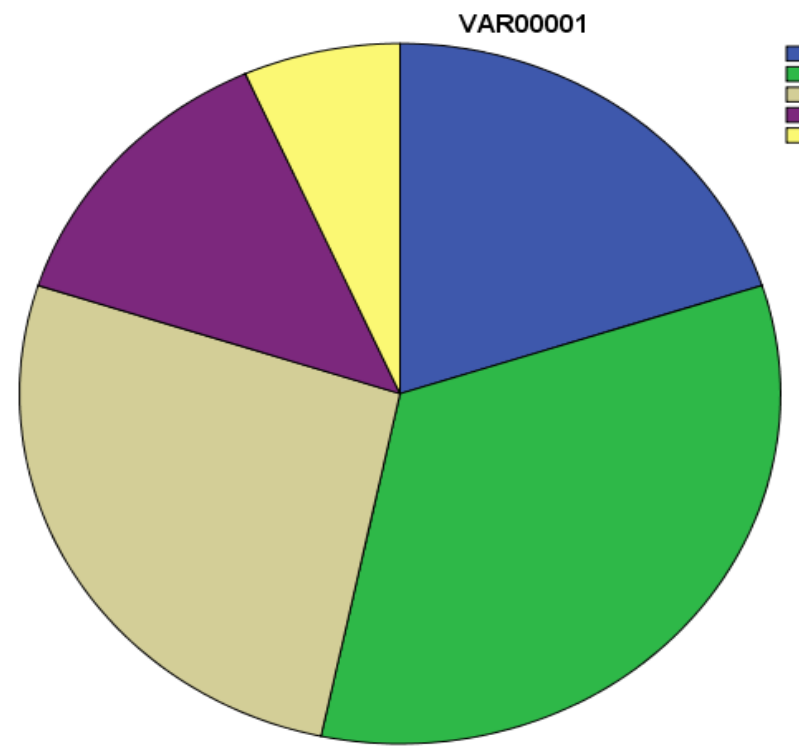

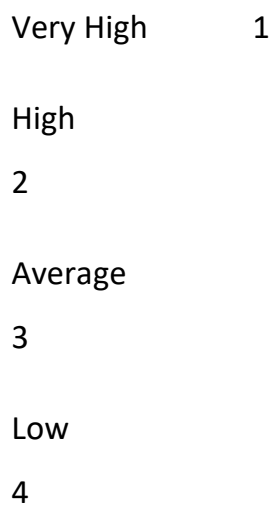
nst the use nedia in school on

corporate policies.

\begin{tabular}{|c|c|c|c|}
\hline $\mathrm{S} / \mathrm{N}$ & Challenges & Frequency & Percentage \\
\hline 1 & Poor access to internet gadgets & 60 & 40 \\
\hline 2 & Unstable source of power & 50 & 33.3 \\
\hline 3 & High cost of browsing & 30 & 20 \\
\hline \multirow[t]{2}{*}{4} & $\begin{array}{l}\text { Inability to operate smart phones/ } \\
\text { computer }\end{array}$ & 10 & 6.7 \\
\hline & Total & 150 & 100 \\
\hline
\end{tabular}

Table 5 above indicates that 60 (40\%) of the respondents are faced with the challenge of poor access to internet gadgets. Fifty (33.3\%) believed that their challenge was unstable source of power. Thirty ( $20 \%$ ) are of the opinion that high cost of browsing is their major challenge, while $10(6.7 \%)$ maintained that their major issue is the public relations practitioners' inability to operate smart phones and or computer systems.

Diagram 4: Histogram representing the degree of various challenges faced by public relations practitioners in the use of social media 


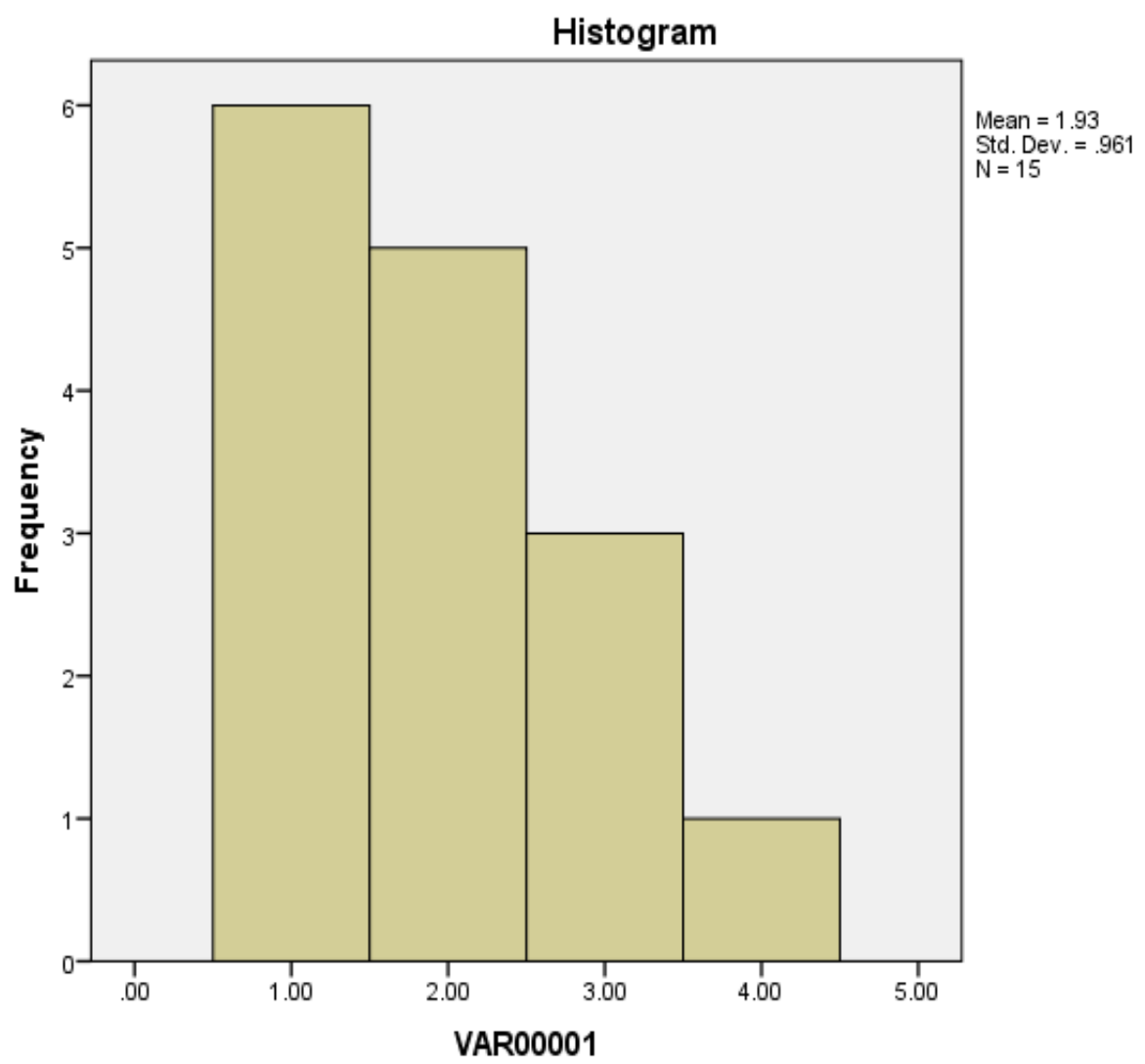

\section{DISCUSSION OF FINDINGS}

In line with the objectives of this study and the research questions raised, the study evaluated the influence of social media in counselling higher school top management on corporate policies in Nigeria. The study sought to ascertain the public relations practitioners use of social media in counselling school management on corporate policies; the types of social media used in counselling the management of institutions of higher learning on corporate policies ; establish the level of utilization of social media by public relations practitioners in counselling management of institutions of higher learning in Nigeria on policy formulation and implementation; determine the influence of the use of social media in counselling school management on corporate policies in institutions of higher learning in Nigeria; and identify the challenges faced by public relations practitioners in using social media to counsel top management of institutions of higher learning on corporate policies.

Findings on whether or not the public relations practitioners in institutions of higher learning in Nigeria use social media to counsel management on corporate policies show that $100 \%$ of the public relations practitioners from the selected institutions use social media to influence school management on corporate policies. This implies that there is adequate use of social media in public relations practice in institutions of higher learning in Nigeria.

It was discovered that public relations practitioners prefer certain social media in influencing top management of institutions of higher learning on corporate policies in Nigeria. Findings 
show that though they use social media such as WhatsApp, Facebook, Twitter, Youtube, and Instagram to interact in the with the school management, it is pertinent to note that the nature of interaction that exist between the public relations practitioners and top school management favours the use of WhatsApp more others. The preference for Whatapp derives from its confidentiality as messages are encrypted and the choice of group membership being the exclusive preserve of the group administrator. This suggests that interaction is strictly limited to those who are permitted to join the interaction, which increases its level of control.

On the extent to which public relations practitioners use social media in counselling top management of institutions of higher learning, findings show that there is a high level of utilization of the social media for counselling school management on corporate policies. Social media has become an accepted innovation for mediating between the management and publics of higher institution of learning in Nigeria. This is evident in the study in that $40 \%$ of the respondents affirmed that their usage of social media is high. This is a welcome development as social media have become a sine - qua - none not only in public relations practice but all human endeavours.

In determining the influence of social media in achieving public relations goal of counselling school management on corporate policies in institutions of higher learning, findings show that social media have made positive impact in the practice of public relations, especially in influencing corporate policies. This position is sustained by 53.3 percent of the respondents who believe that social media enhance their achievement of higher school management counselling on corporate policies formulation and implementation.

However it was discovered that in course of using the social media for counselling top management of institution of higher learning, the public relations practitioners face some challenges. These challenges were partly the responsibilities of school management and partly the responsibilities of the public relations practitioners. Most higher school management do not appear to fully understand how the social media works and so find it difficult to migrate from the old analogue traditional approach to the digital era in which social media is a significant component. The sincere embrace the top management of institution of learning have give to the advent of social media would mean realistic inclusion of social media funding in their annual public relations budget that can cater to the public relations needs for effective deployment of social media for counselling school management.

School management response to change will not be complete without the commensurate response from the public relations practitioners. If management agrees to invest in the infrastructures needed to operate effectively, the users must be ready to make efficient use of the provision made. Incompetence and crassness that stand between public relations practitioners and the efficient use of social media will only eliminated through the readiness of the practitioners to accept the changes brought about in their profession by advent of social media and learn to walk with it through learning how to use social media professionally. 


\section{CONCLUSION}

Social media have become veritable tool for interaction in organisations, especially in policy formulations and implementation as this study has indicated. The public relations practitioners in the institutions of higher learning in Delta State of Nigeria are highly exposed to social media and they use them in public relations practice so, findings have shown the potential of social media in improving the interactivity between school management and the public relations practitioners in policy formulation and implementation.

The study identified various social media that public relations practitioners use in counselling school management on corporate policies. Though findings show that the public relations practitioners use WhatsApp, Facebook, Twitter, Youtube and Instagram in varying degrees their preference is for WhatsApp.

It is imperative to state that the findings show that social media usage by public relations practitioners has made positive impact in influencing school management on policy formulation and implementation. However, the usage of social media has posed some challenges to the public relations practitioners especially in the areas of poor access to internet facilities, unstable source of power supply, high cost of browsing and inability to operate smart phones and computer systems.

\section{Recommendations}

Following from the foregoing conclusions, the recommendations mentioned below will be significant:

1. The usage of social media should be included as part of training of public relations practitioners in institutions of higher learning in Nigeria.

2. Digital interaction platform should be compulsory at the management level of institutions of higher learning in Nigeria. Manual information system should be replaced with digital information system. This will enable easy adaptability.

3. Digital interaction can only be possible when the requisite technology is adequately available. Therefore, service providers should improve in their performance and make network available and accessible.

\section{References}

Agha, E. I. (2017). Influence of social media on public relations practice in University in South-East Nigeria. Global Journal of Human-social science: Arts and HumanitiesPsychology. Vol. 17, issue 3, version 1.0, year 2017. Global Journal Publishers, USA

Ajala, V. O. (2013). Public Relation: in search of professional Experience. Maybest Publishers, Ibadan.

Asemah, E. S., Nwammuo, A. N., Nkwan-Uwaoma, A. O. A. (2017). Theories and Model of communication. Jos University Press, Murtala Mohammed Way, Jos, Plateau State, Nigeria 
European Journal of Business and Innovation Research

Vol.9, No.2, pp. 39-52, 2021

Print ISSN: 2053-4019(Print),

Online ISSN: 2053-4027(Online)

Babatunde, K. A., Innocent, O. A., Ibe, B. O., Comfort, A. O., Emmanuel, U. O. (2013). Social as tools for disseminating Agricultural information to farmers in Plateau State, Nigeria. Journal of Communication and media research. Vol. 5(1), 27-40.

Biri, E. U. (2013). Perception and usage of social media by students of Higher Institutions of Learning in Delta State, Nigeria. Journal of communication and media research. Vol. 5(1), 15-26.

Daramola, A. C. (2003). Fundamentals of professional public relations practice: a global overview, lagos: CMCIC.

Dedekuma, S. E. (2013). Influence of communication on industrial harmony in civil service of Delta State, Nigeria. Journal of communication and media research. Vol. 5(1), 109118.

Emily, M. S. (2015). Examining the use of social media in public relations practice in Kanyan Government. University of Nairobi, college of humanities and social science, school of Journalism and Mass Communication. 20 $0^{\text {th }}$ January, 2020.

Gupta, S. (2002). Statistical methods. New Delhi: sultan Chand and Sons Education Publishers.

Hassan, S. (2014). Mass Communication: principles and Concepts. CBS Publishers and Distributions Pvt Ltd, new Delhi, India.

Igben, H. G. O. (1997). Public Relations Fundamentals. COEWA Publishers, Free-bo printing and Co. Efurun, Delta State.

Martins, S. (2008). Public Relations: the story behind a remarkable renaissance. Speech to the Yale Club, New York, Dec, 2008. http://www.instituteforpr.org/edu-info/pr-the-storybehind-a-remarkable-reaisance1/

Neil, M. S., Lee, N. (2016). Roles in social media: how the practice of public relations is evolving. Public relations Journal. Vol. 10. No. 2 (summer/Fall 2016).

Nwanne, B. U. (2015). Functional public relations. University printing press, Delta State University, Abraka.

Onyechi, N. J., Obono. (2015). Potentials of social media for HIV/AIDS Campaign among Nigeria Youths. Journal of Communication and Media Research. Vol. 7 (1), 219-232.

Wadel, K. (2010). Public Relations now becomes social. March 1, 2010. http://www.yourstory.org/public relations-ny-becomes-social-1217881 